\title{
Cyclic AMP Elevation Is Sufficient to Promote the Survival of Spinal Motor Neurons In Vitro
}

\author{
Martin G. Hanson Jr, ${ }^{1}$ Shiliang Shen, ${ }^{1}$ Anthony P. Wiemelt, ${ }^{2}$ F. Arthur McMorris, ${ }^{2}$ and Ben A. Barres ${ }^{1}$ \\ ${ }^{1}$ Stanford University School of Medicine, Department of Neurobiology, Stanford, California 94305-5125, and \\ 2Wistar Institute, Philadelphia, Pennsylvania 19104
}

\begin{abstract}
The short-term survival of highly purified embryonic spinal motor neurons (SMNs) in culture can be promoted by many peptide trophic factors, including brain-derived neurotrophic factor (BDNF), ciliary neurotrophic factor (CNTF), fibroblast growth factor (FGF), glial-derived neurotrophic factor (GDNF), and hepatocyte growth factor (HGF). We have asked whether these peptides are sufficient to promote the long-term survival of purified E15 SMNs. Contrary to previous reports, we find that when SMNs are cultured in serum-free medium containing a single peptide trophic factor only approximately one-third of the cells survive for $3 \mathrm{~d}$ in culture. When multiple factors are combined, additive effects on survival are observed transiently,
\end{abstract}

Recent studies have suggested that the signaling mechanisms that promote the survival of CNS and peripheral nervous system (PNS) neurons may differ (Meyer-Franke et al., 1995, 1998). The survival of purified, defined types of PNS neurons can be promoted in serum-free medium by single peptide trophic factors (Barbin et al., 1984; Levi-Montalcini, 1987; Barde, 1989, 1990). In addition, PNS neurons survive in the absence of growth factors when their intracellular levels of cAMP are elevated or when they are depolarized (Wakada et al., 1983; Rydell and Greene, 1988; Koike and Tanake, 1991; Franklin and Johnson, 1992). In contrast, several studies have shown that the survival of CNS neurons in culture depends on combinatorial signaling by several peptide trophic factors (Arakawa et al., 1990; Mitsumoto et al., 1994; Meyer-Franke et al., 1995; Wong et al., 1997). Furthermore, whereas PNS neurons are intrinsically responsive to peptide trophic factors, the responsiveness of glutamatergic CNS neurons such as retinal ganglion cells and cerebral cortical neurons depends on signals from neighboring cells (Meyer-Franke et al., 1995, 1998; McAllister et al., 1996). For instance, Meyer-Franke et al. $(1995,1998)$ showed that purified retinal ganglion cells in culture do not respond to a variety of peptide trophic factors unless their levels of cAMP are elevated, which can be induced by depolarization. Thus cAMP elevation induces the retinal ganglion cells to become growth factor-responsive, whereas it induces the PNS neurons to become growth factor-independent.

\footnotetext{
Received April 15, 1998; revised June 26, 1998; accepted July 1, 1998.

This work was supported by grants from the March of Dimes (B.A.B.), by National Institutes of Health Grants NS32122 and CA09171 (F.A.M.), and by the National Multiple Sclerosis Society (F.A.M. and A.P.W.). We thank Genetics Institute for recombinant BMP-2 and BMP-4, Creative Biomolecules for recombinant BMP-7/ OP-1, Genentech for recombinant HGF, and Regeneron for recombinant BDNF and CNTF.

Correspondence should be addressed to Dr. B. A. Barres, Stanford University School of Medicine, Department of Neurobiology, Fairchild Science Building D235, 299 Campus Drive, Stanford, CA 94305-5125. E-mail: barres@stanford.edu Copyright (ㄷ) 1998 Society for Neuroscience $0270-6474 / 98 / 187361-11 \$ 05.00 / 0$
}

but by $7 \mathrm{~d}$ of culture the majority of SMNs has died. Surprisingly, when cAMP levels are elevated, the majority of SMNs extend processes and survive for 1 week in culture in the absence of peptide trophic factors, even in low-density cultures. A combination of five peptide trophic factors, together with cAMP elevation, promotes the long-term survival of most of the SMNs in serum-free culture for 3 weeks. These findings provide useful culture conditions for studying the properties of SMNs and have implications for the treatment of motor neuron diseases.

Key words: rat; trophic factors; forskolin; IBMX; injury; regeneration; bone morphogenetic proteins

Together, these studies indicate that the signaling mechanisms that promote the survival of CNS neurons are more complex than those that promote the survival of PNS neurons.

In this paper we have asked to what extent the survival requirements of spinal motor neurons (SMNs) are like other CNS neurons, including retinal ganglion cells and cerebral cortical neurons. SMNs, unlike these CNS neurons, are cholinergic and project out of the CNS into the PNS; moreover, unlike most CNS neurons they share the property of PNS neurons of being able to survive and regenerate after axotomy. Previous studies have demonstrated that the survival of SMNs depends on Schwann cell and muscle-derived trophic signals and that their survival in culture can be promoted by peptide trophic factors normally produced by muscle, including hepatocyte growth factor (HGF), cardiotrophin-1 (CT-1), and brain-derived neurotrophic factor (BDNF) as well as by peptide trophic factors normally made by Schwann cells, including insulin-like growth factor 1 (IGF-1), ciliary neurotrophic factor (CNTF), neurotrophin-3 (NT-3), and glial-derived neurotrophic factor (GDNF) (Arakawa et al., 1990; Martinou et al., 1992; Sendtner et al., 1992a,b, 1996; Yan et al., 1992; Henderson et al., 1993, 1994; Hughes et al., 1993; Koliatsos et al., 1993; Masu et al., 1993; Neff et al., 1993; Jung et al., 1994; Zurn and Werren, 1994; L. Li et al., 1995; M. Li et al., 1995; Oppenheim et al., 1995; Ebens et al., 1996; McKay et al., 1996; Oppenheim, 1996; Pennica et al., 1996; Wong et al., 1997; Arce et al., 1998). Single peptide trophic factors have been reported to be sufficient to promote the short-term survival of the majority of SMNs in culture (Henderson et al., 1993, 1994; Pennica et al., 1996). These studies, however, were performed in serumcontaining medium, which contains many undefined trophic signals, and peptide trophic factors have been reported to act combinatorially to promote the long-term survival of SMNs (Arakawa et al., 1990; Mitsumoto et al., 1994; Wong et al., 1997). Here we show that single peptide trophic factors are sufficient 
to promote only the short-term survival of a small percentage of SMNs in serum-free medium and that, whereas combinations of two to six peptide trophic factors act additively to promote long-term survival, the so far identified trophic factors for SMNs are insufficient to promote the long-term survival of the majority of SMNs. To our surprise, we found that, as for PNS neurons, cAMP elevation is sufficient to promote the short-term survival and growth of the majority of SMNs in the absence of peptide trophic factors. The long-term survival of the majority of SMNs is promoted by collaborative signaling by several peptides, together with cAMP elevation.

\section{MATERIALS AND METHODS}

Detailed step-by-step protocols for all procedures are available on request (barres@leland.stanford.edu).

\section{Reagents}

Recombinant human trophic factors were obtained from Regeneron (BDNF, CNTF; Tarrytown, NY), Genentech (HGF; South San Francisco, CA), Creative Biomolecules (BMP-7/OP-1; South San Francisco, CA), Genetics Institute (BMP-2, BMP-4; Cambridge, MA). All other recombinant peptides were obtained from Peptrotech (Rocky Hill, NJ).

\section{Preparation of spinal cord suspensions}

Embryonic day 15 (E15) spinal cords were obtained from Sprague Dawley rats (Simonsen Labs, CA) and dissociated enzymatically to make a suspension of single cells, essentially as described by Camu and Henderson (1992). In brief, the ventral half of the spinal cord tissue was incubated at $37^{\circ} \mathrm{C}$ for $15 \mathrm{~min}$ in a trypsin solution $(0.05 \%$; Life Technologies, Gaithersburg, MD) in calcium-free and magnesium-free PBS (Life Technologies). Then the tissue was washed with $10 \%$ fetal calf serum and triturated in a Leibowitz-15 (L-15) solution containing bovine serum albumin (4\% BSA; Sigma, St. Louis, MO) and DNase (0.004\%; Sigma).

\section{Purification of spinal motor neurons}

Spinal motor neurons from E15 rats were purified to $>85 \%$ purity as determined by islet- 1 immunostaining essentially as described by Camu and Henderson (1992). The SMNs were purified from the spinal cord cell suspensions by using a density gradient, followed by sequential immunopanning to yield 20,000 SMNs per E15 spinal cord (Ericson et al., 1992).

Gradient. The spinal cord cell suspension was centrifuged through a $4 \%$ BSA cushion at $125 \times g$ for $10 \mathrm{~min}$. The pellet was resuspended and centrifuged through $6.8 \%$ metrizamide $(\mathrm{w} / \mathrm{v}$; Sigma) at $500 \times g$ for 15 min to remove cells of higher density from the spinal cell suspension. The lower-density cells were resuspended in L-15 and centrifuged through a $4 \%$ BSA cushion at $125 \times g$ for $10 \mathrm{~min}$.

Preparation of panning dishes. A Petri dish $(100 \times 15 \mathrm{~mm}$; Fisher Scientific, Pittsburgh, PA) was incubated with $12 \mathrm{ml}$ of Tris buffer solution, $\mathrm{pH} 9.5$, with $40 \mu \mathrm{g} / \mathrm{ml}$ affinity-purified goat anti-mouse $\mathrm{IgG}$ $(\mathrm{H}+\mathrm{L})$ (Jackson ImmunoResearch, West Grove, PA) for $12 \mathrm{hr}$ at $4^{\circ} \mathrm{C}$. The dish was washed three times with $8 \mathrm{ml}$ of PBS and then was incubated with $10 \mathrm{ml}$ of anti-p75 monoclonal IgG supernatant (MAB 192 , Eric Shooter) for $12 \mathrm{hr}$ at $4^{\circ} \mathrm{C}$. The supernatant was removed and the plate was washed three times with PBS. A Petri dish coated with an anti-galactocerebroside (GC) monoclonal supernatant was prepared similarly.

Panning procedure. The spinal cell suspension was resuspended in 10 $\mathrm{ml}$ of L-15 and incubated on the Petri dish coated with anti-GC antibodies to remove microglia and oligodendrocytes. The nonadherent cells were placed in a $37^{\circ} \mathrm{C}$ incubator for $1 \mathrm{hr}$ to allow new undigested $\mathrm{p} 75$ to appear on the cell surface; this step is crucial, because the extracellular domain of $\mathrm{p} 75$ contains $\sim 10$ trypsin cleavage sites; thus $\mathrm{p} 75$ is digested in large part during the preparation of the spinal cord cell suspension. To select for motor neurons, we filtered the spinal cell suspension through Nitex mesh (15 $\mu \mathrm{M}$, Tetko, Elmsford, NY) to remove any cell aggregates and placed the suspension on the Petri dish coated with anti-p75 antibodies for $1 \mathrm{hr}$ at room temperature. The nonadherent cells were removed by washing the dish five times with PBS.

Removal of adherent cells from the panning plate. A trypsin solution (4 $\mathrm{ml} ; 0.125 \%$ ) was prepared by diluting a trypsin $20 \times$ stock (Sigma) into Earle's balanced salt solution. Cells on the panning dish were incubated with this solution for $2 \mathrm{~min}$ in a $10 \% \mathrm{CO}_{2}$ incubator at $37^{\circ} \mathrm{C}$. The cells were dislodged by gently pipetting trypsin solution around the plate. Ten milliliters of a $25 \%$ FCS solution were added to inactivate the trypsin, and the cells were centrifuged and collected as above.

\section{Culture of purified motor neurons}

Approximately 2500 purified motor neurons were cultured in 96-well plates that had been coated with merosin $(2 \mu \mathrm{g} / \mathrm{ml}$; Life Technologies) in $100 \mu \mathrm{l}$ of serum-free medium containing L-15 and sodium bicarbonate. The serum-free additives that were used included BSA, selenium, putrescine, thyroxine, and transferrin [modified from Bottenstein and Sato (1979), as previously described in Lillien and Raff (1990)] (B-S medium) pyruvate $(1 \mathrm{mM})$, glutamine $(1 \mathrm{~mm})$, penicillin/streptomycin, and trophic factors as indicated. In some cases, when indicated, the serum-free additive B27 (Life Technologies; Brewer et al., 1993) also was added at a dilution of 1:50. The percentage of surviving cells was assessed after $3 \mathrm{~d}$ by MTT assay (see below). All values were normalized to the percentage of surviving cells at $1 \mathrm{hr}$ after plating. All peptide trophic factors were used at a plateau concentration of $10 \mathrm{ng} / \mathrm{ml}$, as established by doseresponse curves, except for NT-3, NT-4/5, transforming growth factor $\alpha$ $(\mathrm{TGF} \alpha)$, TGF $\beta 2$, and TGF $\beta 3$, which were used at $50 \mathrm{ng} / \mathrm{ml}$. Insulin was used at $5 \mu \mathrm{g} / \mathrm{ml}$.

\section{MTT survival assay}

The MTT survival assay was performed as described by Mosmann (1983). MTT [3-(4,5-dimethylthiazol-2-yl)-2,5-diphenyl tetrazolium bromide; Sigma] was dissolved in PBS at $5 \mathrm{mg} / \mathrm{ml}$ and sterilized by passage through a Millipore filter $(0.22 \mu \mathrm{m}$; Millipore, Bedford, MA). This stock solution was added to the culture well $(1: 9)$ and incubated at $37^{\circ} \mathrm{C}$ for 1 hr. Viable cells with active mitochondria cleaved the tetrazolium ring into a visible dark blue formazan reaction product. The viable and dead cells in each well were counted by bright-field microscopy. In all cases the percentage of survival determined by the MTT assay was nearly identical to the values determined by morphology alone. All values are given as the mean \pm SEM of at least three cultures. All experiments were repeated at least three times. The results of representative experiments are shown.

\section{Immunofluorescence staining}

After fixation with $4 \%$ paraformaldehyde for $10 \mathrm{~min}$ at room temperature, the cells were incubated for $30 \mathrm{~min}$ in a $50 \%$ goat serum solution containing $1 \% \mathrm{BSA}$ and $100 \mathrm{~mm}$ L-lysine to block nonspecific binding and containing Triton X-100 $0.4 \%$ to permeabilize the membrane. To stain for purity of spinal motor neurons, we incubated cells in monoclonal islet-1/2 antibody (4D5; Developmental Studies Hybridoma Bank, University of Iowa, Iowa City, IA), respectively, followed by fluoresceincoupled goat anti-mouse $\mathrm{IgG}(10 \mu \mathrm{g} / \mathrm{ml}$; Jackson Laboratories, Bar Harbor, ME). The coverslips were mounted in Citifluor on glass slides, sealed with nail varnish, and examined with a Nikon fluorescence microscope.

Cyclic AMP immunostaining was performed with a polyclonal antiserum and with a procedure developed by Wiemelt et al. (1997). In brief, an antibody to cAMP was prepared by immunizing a rabbit with a protein carrier coupled to cAMP with acrolein. For immunostaining, acutely isolated purified SMNs were incubated for $60 \mathrm{~min}$ in Neurobasal with $0.2 \%$ BSA containing either nothing, forskolin $(10 \mu \mathrm{M})$, IBMX $(0.1$ $\mathrm{mM})$, forskolin and IBMX together, or trophic factors as indicated. The cells were fixed with $5.5 \%$ acrolein $(\mathrm{v} / \mathrm{v})$ in a sodium acetate-buffered solution $(0.1 \mathrm{M}, \mathrm{pH} 4.75)$ for $1 \mathrm{hr}$ at room temperature. The cells were washed in a quenching solution containing glycine $(1 \mathrm{mg} / \mathrm{ml})$ for $30 \mathrm{~min}$, followed by sodium borohydride $(1 \%)$ for $30 \mathrm{~min}$. Then the cultures were stained by incubating them in the anti-cAMP antiserum diluted 1:50 in a Tris-HCl solution (50 mM; $\mathrm{pH} 7.5)$ containing Triton X-100 (0.5\%) and goat serum $(50 \%)$ overnight. The cultures were rinsed three times in the Tris solution and incubated in a biotin-conjugated goat anti-rabbit IgG (Amersham, Arlington Heights, IL) at $10 \mu \mathrm{g} / \mathrm{ml}$ for $1 \mathrm{hr}$. The cultures were rinsed three times in the Tris solution and incubated in a FITCconjugated streptavidin solution $(10 \mu \mathrm{g} / \mathrm{ml})$ for $1 \mathrm{hr}$. Finally, the cultures were rinsed in the Tris solution three times and then mounted as described above. The cAMP antiserum is highly specific for cAMP (Wiemelt et al., 1997).

\section{Cellular cAMP assay}

The cAMP radioimmunoassay was performed by using the BIOTRAK cAMP $\left[{ }^{125} \mathrm{I}\right]$ assay system (Amersham RPA 509). In all, 5000 SMNs were 


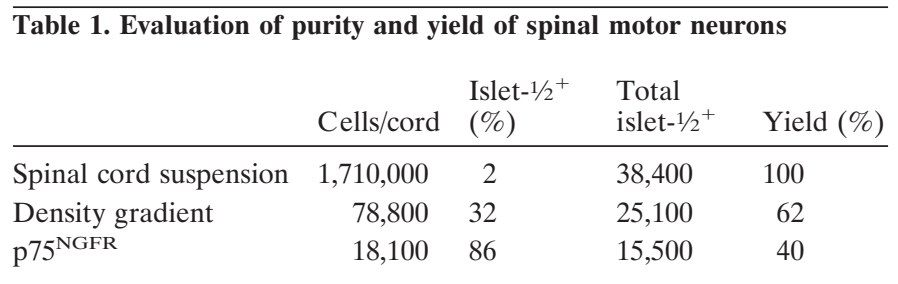

$\overline{\text { Approximately 10,000 E15 spinal cells were plated in triplicate on merosin-coated }}$ coverslips in 24-well Falcon plates in $500 \mu \mathrm{l}$ of serum-free medium. After $24 \mathrm{hr}$ in culture, the percentage of SMNs was determined, using immunostaining with the 4D5 islet- $1 / 2$ monoclonal antibody.

plated per well in a 24-well plate and incubated for $24 \mathrm{hr}$ in serum-free medium containing HGF, BDNF, CNTF, and GDNF. Then the cells were washed three times for $20 \mathrm{~min}$ intervals with $0.2 \% \mathrm{BSA}$. The cells were incubated for 1,6 , and $24 \mathrm{hr}$ at $37^{\circ} \mathrm{C}$ with $0.2 \%$ BSA containing either nothing, forskolin $(10 \mu \mathrm{M})$, IBMX $(0.1 \mathrm{mM})$, forskolin and IBMX together, trophic factors, or forskolin and trophic factors as indicated. After incubation, the cells were permeabilized with ice-cold ethanol. The extracts were lyophilized in a speed vacuum (SC110A, Savant Industries, Farmingdale, NY) and stored at $-20^{\circ} \mathrm{C}$ until analysis. The acetylation protocol was used to increase the signal size of the amount of cAMP. The extracts were solubilized in assay buffer and then diluted in a mixture of one part acetic anhydride to two parts triethylamine. $3^{\prime}, 5^{\prime}$ Cyclic phosphoric acid $2^{\prime}-0$-succinyl-3-[ $\left.{ }^{125} \mathrm{I}\right]$-iodotyrosine methyl ester, which binds to cyclic AMP, was added, followed by the anti-cAMP antiserum. After incubation for $15-18 \mathrm{hr}$ at $4^{\circ} \mathrm{C}$, Amerlex-M secondary antibody was added to the sample, and the precipitate was obtained by centrifugation. Each sample was counted for $60 \mathrm{sec}$ by an autosampling gamma scintillation counter (Beckman, Fullerton, CA), and the cAMP values were obtained with a standard curve.

\section{RESULTS}

\section{Evaluation of yield and purity of the spinal motor neurons}

The procedure for purifying SMNs developed by Camu and Henderson $(1992,1994)$ involves two steps: first, a density gradient is used to select low-density cells from an E15 spinal cord cell suspension; second, immunopanning is used to select the lowdensity cells that express the p75 nerve growth factor receptor. We modified this procedure by adding a $1 \mathrm{hr}$ recovery step to allow for the reappearance of $\mathrm{p} 75$ on cell surfaces, because $\mathrm{p} 75$ has 10 trypsin cleavage sites and is digested in large part during the enzymatic procedure used to prepare the spinal cord cell suspensions (see Materials and Methods). In addition, we added an initial panning step with an irrelevant antibody to eliminate microglia from the cell suspension. We assessed the purity and yield of our SMN preparations with the 4D5 anti-islet-1/2 monoclonal antibody, which specifically labels spinal motor neurons (Ericson et al., 1992; Tsuchida et al., 1994; Yamamoto et al., 1997). These modifications allowed us to obtain a fourfold increase in our yield of SMNs as well as an increase in their purity. Although only $2 \%$ of the cells in the E15 spinal cord cell suspension were islet- $1 / 2^{+}$, the purity of the SMN preparation was $86 \%$ (Table 1; Fig. 1). The remaining 14\% of the cells were neurons, because they did not take up BrdU or stain with glial or fibroblast markers and they did stain with an anti-neuron-specific enolase antiserum.

\section{Effects of single peptide tropic factors on short-term survival of SMNs in vitro}

To determine the ability of single peptide trophic factors to promote SMN survival, we cultured the purified E15 SMNs in serum-free medium on a merosin substrate (see Materials and Methods). After $3 \mathrm{~d}$ in culture we assessed their survival by using an MTT assay, as described previously (see Materials and Meth-

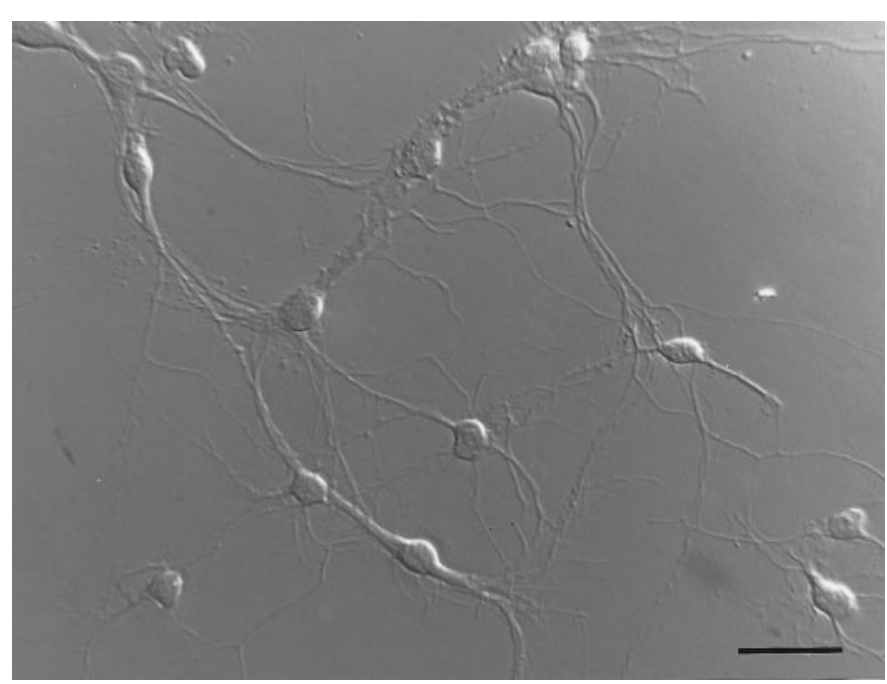

Figure 1. Spinal motor neurons after $24 \mathrm{hr}$ in culture. $A$, Phase-contrast micrograph. $B$, Immunofluorescence micrograph of the same field as in $A$, stained with the 4D5 anti-islet-1/2 monoclonal antibody. The SMNs were cultured in BDNF, CNTF, GDNF, HGF, forskolin, and IBMX. Scale bar, $50 \mu \mathrm{m}$.

Table 2. Effects of single neurotrophic factors on spinal motor neuron survival in short-term culture

\begin{tabular}{lllr}
\hline None & $11 \pm 2$ & HGF & $28 \pm 1$ \\
Insulin & $37 \pm 1$ & GGF & $10 \pm 1$ \\
IGF-1 & $32 \pm 2$ & TGF $\alpha$ & $22 \pm 1$ \\
NGF & $15 \pm 1$ & PDGF-AA & $8 \pm 1$ \\
BDNF & $38 \pm 1$ & PDGF-BB & $24 \pm 1$ \\
NT-3 & $30 \pm 1$ & BMP-2 & $27 \pm 1$ \\
NT-4/5 & $20 \pm 1$ & BMP-4 & $28 \pm 2$ \\
CNTF & $29 \pm 1$ & BMP-7 & $28 \pm 2$ \\
LIF & $31 \pm 1$ & TGF $\beta 2$ & $22 \pm 1$ \\
IL-6 & $15 \pm 2$ & TGF $\beta 3$ & $23 \pm 1$ \\
IL-3 & $12 \pm 1$ & GDNF & $38 \pm 2$ \\
IL-7 & $11 \pm 2$ & Persephin & $28 \pm 2$ \\
bFGF & $38 \pm 2$ & Neurturin & $25 \pm 2$ \\
\end{tabular}

Approximately 3000 purified SMNs were plated in triplicate on merosin-coated 96-well plates in $100 \mu \mathrm{l}$ of serum-free medium containing a plateau concentration of a single peptide trophic factor as indicated. After $3 \mathrm{~d}$ of culture, the percentage of cells surviving was determined, using the MTT assay (means \pm SEM, $n=3$, of a representative experiment is shown; all experiments were repeated at least three times).

ods). In the absence of added growth factors, the majority of the cells died within $3 \mathrm{~d}$ with the characteristic morphology of apoptosis. The nucleus and cytoplasm of the apoptotic cells were shrunken, and the cells did not metabolize MTT. Interestingly, as previously reported (Henderson et al., 1993), $\sim 10 \%$ of the cells did not die in the absence of growth factors and appeared healthy, with a large soma and long processes (Table 2). These cells were not contaminating cells but were probably motor neurons because they were islet $-1 / 2^{+}$(data not shown).

We tested whether plateau concentrations of single peptide growth factors previously shown to promote the survival of SMNs in vitro and to be produced normally by Schwann cells or muscle cells would promote their survival. Over the same $3 \mathrm{~d}$ culture period, as previously reported, we found that a large variety of peptides was sufficient to significantly promote the survival of the SMNs, although typically single peptides could promote only the 
survival of $\sim 20-35 \%$ of the cells for a few days or only $10-25 \%$ of the cells if the $10 \%$ that would survive without signals were not counted (Table 2). These peptides included CNTF, leukemia inhibitory factor (LIF), BDNF, NT-3, NT-4/5, nerve growth factor (NGF), IGF-1, fibroblast growth factor (FGF), GDNF, and HGF. In addition, we observed that several recently described peptides called bone morphogenetic proteins 2, 4, and 7 (BMPs), which are members of the TGF $\beta$ superfamily and are produced by a variety of cell types including Schwann cells (Bitgood and McMahon, 1995; Hogan, 1996; Lein et al., 1996), also promoted the survival of the SMNs (Table 2). In all cases, the viability of SMNs cultured in single peptide trophic factors in serum-free medium dropped off considerably after $3 \mathrm{~d}$; by 1 week almost all of the cells were dead. The omission of merosin as the substrate resulted in significantly less survival (data not shown).

\section{Effects of multiple peptide tropic factors on short-term survival of spinal motor neurons}

Because single factors did not promote $100 \%$ survival of spinal motor neurons at $3 \mathrm{~d}$ (Table 2), we investigated whether combinations of peptide trophic factors used at plateau concentrations would improve short-term survival. Because factors fell into several classes according to the receptors and signal transduction pathways that they activate, we first tested combinations of factors within the same class and found that additive effects on survival did not occur, as expected. For example, over a $3 \mathrm{~d}$ culture period neither the cytokines CNTF and LIF were additive, nor were the neurotrophins NT-3, BDNF, NT-4/5, and NGF (data not shown).

In contrast, combinations of factors from different classes nearly always had an additive effect on the survival of the SMNs (Table 3). More cells survived in a combination of three factors than in two factors, and short-term survival progressively increased as a function of the number of trophic factors combined. As the percentage of surviving cells approached $100 \%$, the additive effects of four or more factors became less noticeable. When we combined four or more factors from different classes, regardless of which four factors, we were able to promote the survival of the majority of SMNs for $3 \mathrm{~d}$ in culture (Table 3). Surviving neurons quickly extended dendrites and axons (Fig. 2). The rate and amount of process outgrowth correlated closely with the degree of survival.

Although combinations of multiple factors could promote survival of most of the SMNs for $3 \mathrm{~d}$, the percentage of surviving cells fell rapidly with increasing time in culture (see below), raising the question of whether there are important peptide trophic factors for SMNs that have not yet been identified. To test this possibility, we made extracts of developing embryonic and postnatal rat brain, muscle, sciatic nerve, and spinal cords. The effects of the extracts separately and in combination with growth factors on the short-term survival of SMNs were determined. Although the extracts prepared from spinal cord, sciatic nerve, and muscles each promoted the survival of approximately onethird of the SMNs in culture, their effects were not additive with combinations of three or more peptide factors (data not shown).

\section{Effects of steroid hormones, oxygen tension, and density on SMN survival}

Steroid hormones have been reported previously to enhance the survival of SMNs and other neurons and, except for progesterone, were not present in our serum-free medium. We prepared a modified B-S medium that lacked progesterone and assessed the ability of single steroid hormones added to the medium to pro-
Table 3. Effects of multiple neurotrophic factors on spinal motor neurons in short-term culture

Survival $(\%)$

\begin{tabular}{ll} 
Two factors & \\
BDNF + GDNF & $46 \pm 2$ \\
BDNF + HGF & $48 \pm 1$ \\
FGF + BMP-7 & $38 \pm 1$ \\
BMP-4 + insulin & $45 \pm 3$ \\
Three factors & $63 \pm 2$ \\
BDNF + CNTF + HGF & $66 \pm 2$ \\
BDNF + FGF + GDNF & $65 \pm 2$ \\
FGF + BMP-7 + insulin & $75 \pm 1$ \\
Four factors & $72 \pm 1$ \\
FGF + HGF + BMP-7 + insulin & $75 \pm 1$ \\
CNTF + FGF + NT-3 + insulin & $80 \pm 1$ \\
BDNF + CNTF + GDNF + insulin & $81 \pm 1$ \\
Five factors & \\
BDNF + CNTF + GDNF + FGF + insulin & \\
GDNF + FGF + HGF + BMP-7 + insulin & \\
Six factors & \\
BDNF + CNTF + GDNF + FGF + BMP-7 & \\
$\quad+$ insulin & \\
BDNF + CNTF + GDNF + FGF + HGF + & \\
$\quad$ insulin & \\
Seven factors & \\
BDNF + CNTF + GDNF + FGF + HGF + & \\
$\quad$ BMP-7 + insulin & \\
Eight factors & \\
BDNF + CNTF + GDNF + FGF + HGF + & \\
$\quad$ BMP-7 + NT-3 + insulin & \\
\hline
\end{tabular}

$\overline{\text { Approximately } 3000 \text { purified E15 spinal motor neurons cells were plated in triplicate }}$ in merosin-coated 96-well Falcon plates in $100 \mu \mathrm{l}$ of L-15 medium without insulin, containing a plateau concentration in various combinations of the appropriate factor. After $3 \mathrm{~d}$ of culture, the percentage of cells surviving in each well was determined, using the MTT assay (see Materials and Methods; means \pm SEM, $n=$ 3 , of a representative experiment is shown; all experiments were repeated at least three times).

mote SMN survival. Steroid hormones were insufficient by themselves to promote SMN survival, so we also added CNTF, $\mathrm{BDNF}$, and insulin to the medium. After $3 \mathrm{~d}$ in culture, the survival of the SMNs was assessed with the MTT assay (Table 4). Whereas progesterone, retinoic acid, and thyroid hormone did not promote survival, a weak but statistically significant enhancement of survival was observed with dihydrotestosterone, estradiol, and hydrocortisone. Moreover, their survival-promoting effects were additive (Table 4).

SMNs have been shown previously to be sensitive to oxidative damage, raising the question of whether the high ambient oxygen tension of $20 \%$, which is approximately four times higher than the oxygen levels that SMNs normally are exposed to in vivo, could be toxic to the cultured SMNs. To test this possibility, we compared the survival of SMNs cultured at 5 and $20 \%$ oxygen in a waterjacketed oxygen-controlling incubation chamber (Forma Scientific, Marietta, $\mathrm{OH}$ ) for $3 \mathrm{~d}$ in serum-free medium containing HGF, BDNF, or CNTF. The percentages of cells that survived in each condition in the 5 and $20 \%$ oxygen atmospheres were nearly identical (data not shown). Thus the high oxygen levels typically used in our cultures do not account for the rapid fall off in survival of the SMNs after $3 \mathrm{~d}$ in culture.

Last, we studied the effects of cell density on survival of the SMNs in serum-free medium containing a single peptide trophic 

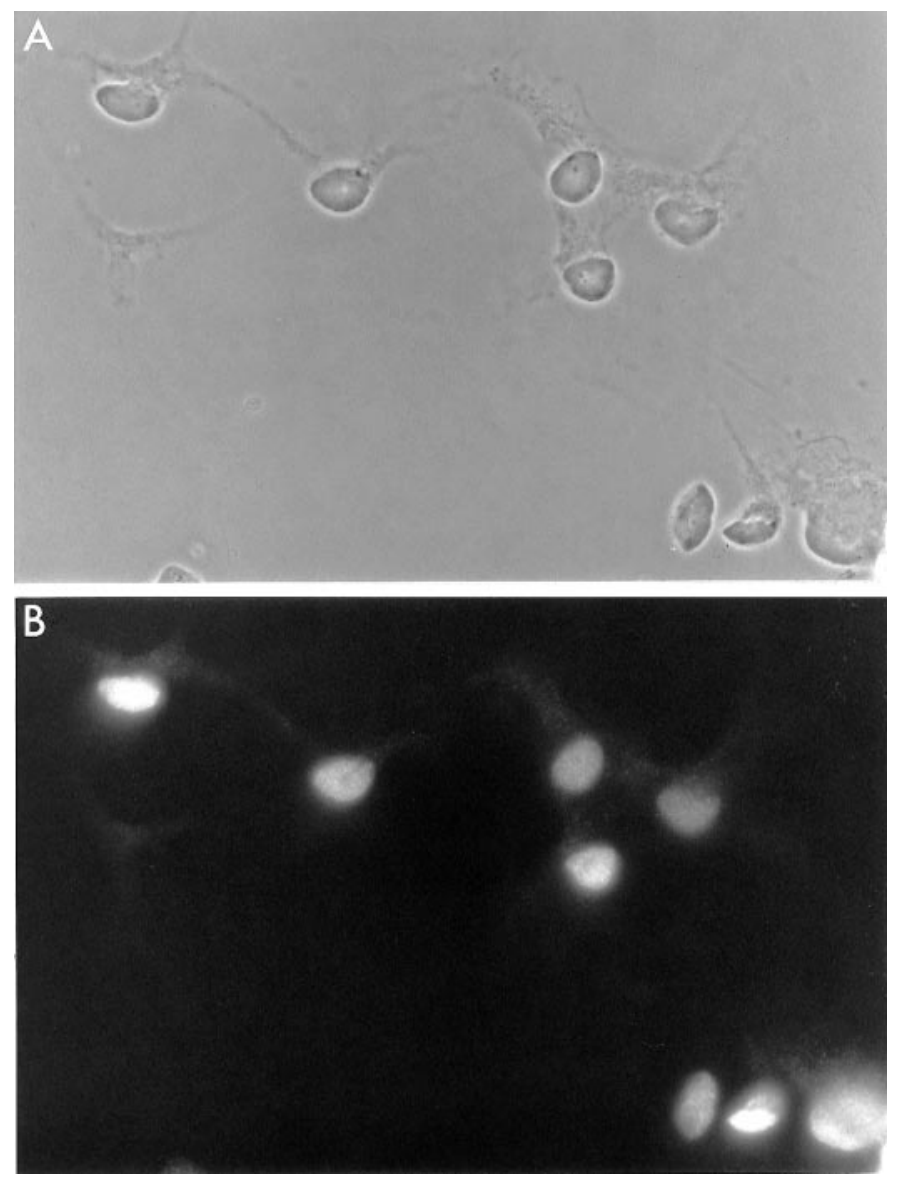

Figure 2. Hoffman micrograph of purified spinal motor neurons in culture. SMNs were cultured for $24 \mathrm{hr}$ in BDNF, CNTF, GDNF, HGF, forskolin, and IBMX. Scale bar, $75 \mu \mathrm{m}$.

$\overline{\text { Table 4. Effects of hormones on spinal motor neurons survival in short- }}$ term culture

\begin{tabular}{ll} 
& Survival (\%) \\
\hline None & $48 \pm 1$ \\
Retinoic acid & $49 \pm 1$ \\
Progesterone & $50 \pm 1$ \\
Thyroid hormone (T3) & $51 \pm 1$ \\
DHT & $55 \pm 1$ \\
Hydrocortisone & $57 \pm 1$ \\
$b$-Estradiol & $58 \pm 1$ \\
$b$-Estradiol + DHT + hydrocortisone & $67 \pm 2$
\end{tabular}

SMNs were plated in serum-free medium containing BDNF, CNTF, and plateau concentrations of various hormones. After $3 \mathrm{~d}$ of culture, the survival was measured with an MTT assay (means \pm SEM, $n=3$, of a representative experiment is shown; all experiments were repeated at least three times).

factor, either BDNF or HGF. After $3 \mathrm{~d}$ in culture, survival at low density was two to three times lower than at the high density we usually used for our experiments (Fig. 3).

\section{Effects of cyclic AMP elevation on the survival of spinal motor neurons}

cAMP elevation has been reported previously to enhance the survival of CNS neurons by enhancing their responsiveness to peptide trophic factors and the survival of PNS neurons by making them independent of growth factors. Thus we next exam-

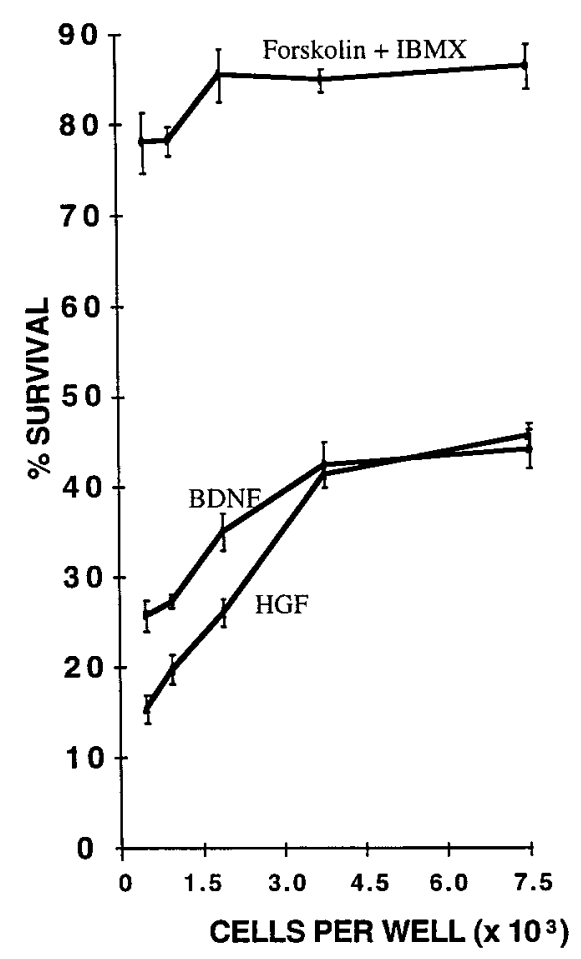

Figure 3. The effect of cell density on spinal motor neuron survival. Purified spinal motor neurons were cultured in serum-free medium containing BDNF, HGF, or forskolin and IBMX at the indicated densities. The percentage of cells surviving was determined by the MTT assay after $3 \mathrm{~d}$ of culture (results are mean $\pm \mathrm{SEM}, n=3$; a representative experiment is shown; all experiments were repeated at least three times).

ined the effects of the pharmacological elevation of cAMP on SMN survival. Forskolin $(10 \mu \mathrm{M})$, an activator of adenylyl cyclase, is sufficient to elevate cAMP levels in purified retinal ganglion cells in culture, but it is not sufficient to elevate cAMP levels in sympathetic neuron cultures (Buckmaster and Tolkovsky, 1994; Meyer-Franke et al., 1998), where the addition of a phosphodiesterase inhibitor, IBMX, is also necessary. Thus we assessed the effects of pharmacological agents on cAMP levels by immunostaining with a cAMP-specific polyclonal antiserum and by radioimmunoassay (see Materials and Methods).

The SMN cultures were treated with serum-free medium containing either nothing, forskolin $(10 \mu \mathrm{M})$, IBMX $(0.1 \mathrm{mM})$, forskolin together with IBMX, or a combination of six peptide trophic factors for $60 \mathrm{~min}$, and then the cultures were stained with the cAMP antibody. Only very low levels of basal immunoreactivity were detectable in the control cultures (Fig. $4 A$ ) and in cultured treated with growth factors alone (Fig. 4B), forskolin alone (Fig. 4C), or IBMX alone (Fig. 4D). The combination of forskolin and IBMX together, however, produced intense cAMP immunoreactivity throughout the cell bodies and processes (Fig. $4 E, F)$. Interestingly, although nearly all cells stained significantly above control, $\sim 10 \%$ of the cells were labeled particularly strongly (data not shown).

These increases in cAMP immunoreactivity corresponded closely with cAMP contents as measured by a radioimmunoassay (see Materials and Methods). Although cAMP levels in the SMNs were not increased significantly after $1 \mathrm{hr}$ of treatment with forskolin or IBMX alone, the amount of cAMP was approximately doubled after $24 \mathrm{hr}$ of culture (Fig. 5). The combination 

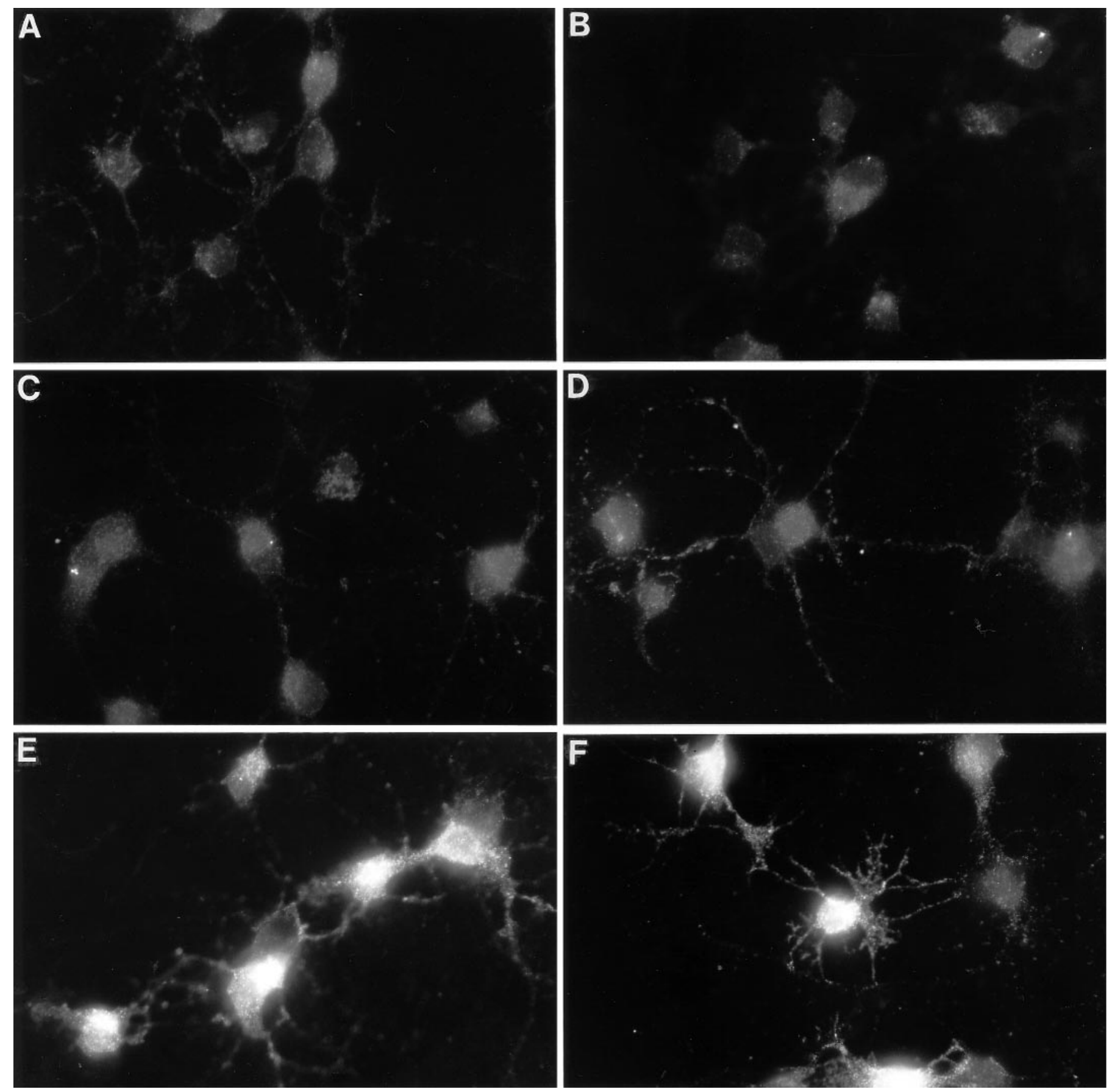

Figure 4. cAMP immunoreactivity in spinal motor neurons in culture. Purified spinal motor neurons in serum-free medium were treated for 1 hr before immunostaining in nothing $(A)$, six peptides together (BDNF, CNTF, IGF-1, HGF, FGF, and GDNF; $B$ ), forskolin $(C)$, IBMX $(D)$, or forskolin together with IBMX $(E, F)$. Scale bar, $50 \mu \mathrm{m}$.

of forskolin plus IBMX together increased cAMP levels nearly 10-fold when measured both after 1 and $24 \mathrm{hr}$ of culture (Fig. 5).

To determine whether cAMP elevation was sufficient to promote survival in the absence of added growth factors, we cultured the SMNs for $3 \mathrm{~d}$ in serum-free medium containing pharmacological agents to elevate cAMP. IBMX alone and forskolin alone each weakly promoted SMN survival (Fig. 5). When forskolin and IBMX were combined, however, the majority of SMNs survived for $3 \mathrm{~d}$ (Fig. 5) and rapidly extended dendrites and axons, although trophic peptides were not added to the culture medium. The effects of cAMP elevation on survival and process outgrowth are not likely to be attributed to enhanced production of autocrine peptides by the SMNs, because even when they were cultured at very low density, a majority of SMNs still survived and extended processes (see Fig. 3). The effects of forskolin and IBMX were mimicked by the cell membrane-permeant cAMP analog, chlorophenylthio-cAMP (CPT-cAMP, $125 \mu \mathrm{M}$; Fig. 6), which was also sufficient to promote the survival of the majority of SMNs. The enhancement of survival induced by cAMP elevation was blocked by the specific protein kinase A inhibitors, 


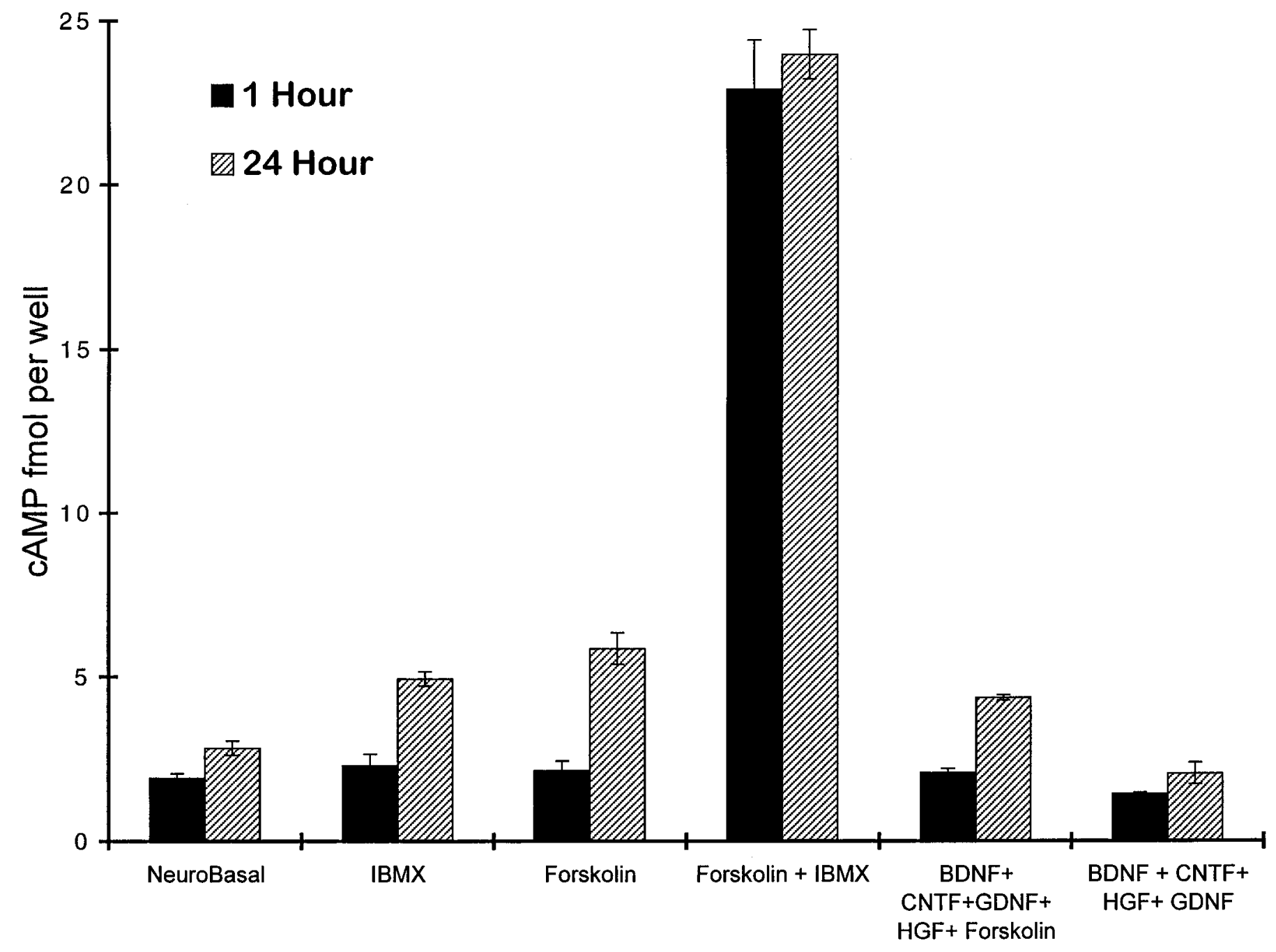

Figure 5. cAMP content of SMNs in culture. Purified SMNs in serum-free culture were treated for 1 or 24 hr in the indicated conditions (see Materials and Methods), and then their cAMP levels were measured by radioimmunoassay. All values represent mean \pm SEM $(n=4)$ of a representative experiment; all experiments were repeated at least three times.

H89 (10 $\mu \mathrm{M}$; Chijiwa et al., 1990) and Rp-cAMP (200 $\mu \mathrm{M}$; Botelho et al., 1988).

Activation of several other second messenger pathways did not mimic the effects of cAMP elevation. CPT-cGMP $(125 \mu \mathrm{M})$, which is not degraded by phosphodiesterases, had a weak and transient effect (Fig. 6), as previously noted (Weill and Green, 1984). However, CPT-cGMP significantly enhanced intracellular cAMP levels in the SMNs, possibly by slowing its rate of degradation (our unpublished observations). The phorbol ester tissue plasminogen activator (TPA; $10 \mathrm{nM}$ ), which activates protein kinase $\mathrm{C}$, and depolarization by high extracellular $\mathrm{K}^{+}(50 \mathrm{mM})$ or glutamate receptor agonists did not mimic the effects of cAMP elevation (data not shown). For instance, only $2.6 \pm 0.5$ (mean \pm SEM; $n=3$ ) of SMNs survived for $3 \mathrm{~d}$ in high $\mathrm{K}^{+}$, which did not elevate cAMP levels. Interestingly, the survival-promoting effects of CPT-cAMP were mimicked when pertussis toxin $(50 \mathrm{ng} / \mathrm{ml})$, an inhibitor of a $\mathrm{G}_{\mathrm{i}}$-protein that inhibits adenylyl cyclase, was combined with IBMX (Fig. 6), suggesting that the SMNs in culture may be secreting a substance that decreases their cAMP levels. Acetylcholine was an obvious candidate because it has been shown to activate muscarinic receptors coupled to $\mathrm{G}_{\mathrm{i}^{-}}$ protein; however, atropine, an antagonist of muscarinic receptors, did not mimic the effect of pertussis toxin (data not shown).

\section{Effects of growth factors and cAMP elevation on long-term survival of SMNs}

Last, we asked to what extent combinations of peptide trophic factors and cAMP elevation could promote the long-term survival of SMNs in culture. Remarkably, cAMP elevation alone was sufficient to promote the survival of the majority of cells for 1 week in culture; however, by the end of 2 weeks most of the cells had died (Fig. 7). Similarly, a combination of five peptide trophic factors (BDNF, CNTF, GDNF, HGF, and insulin) promoted the survival of the majority of the SMNs for 1 week, but at 2 weeks only approximately one-half were still alive; by the end of 3 weeks most had died. When the combination of five peptide trophic factors was combined with forskolin and IBMX to elevate cAMP levels, however, nearly two-thirds of the SMNs were still alive at 2 weeks. When the serum-free additive B27 (Brewer et al., 1993), which contains lipid precursors, antioxidants, and several steroid hormones, including hydrocortisone, also was added, the majority of cells survived for 3 weeks (Fig. 7). 


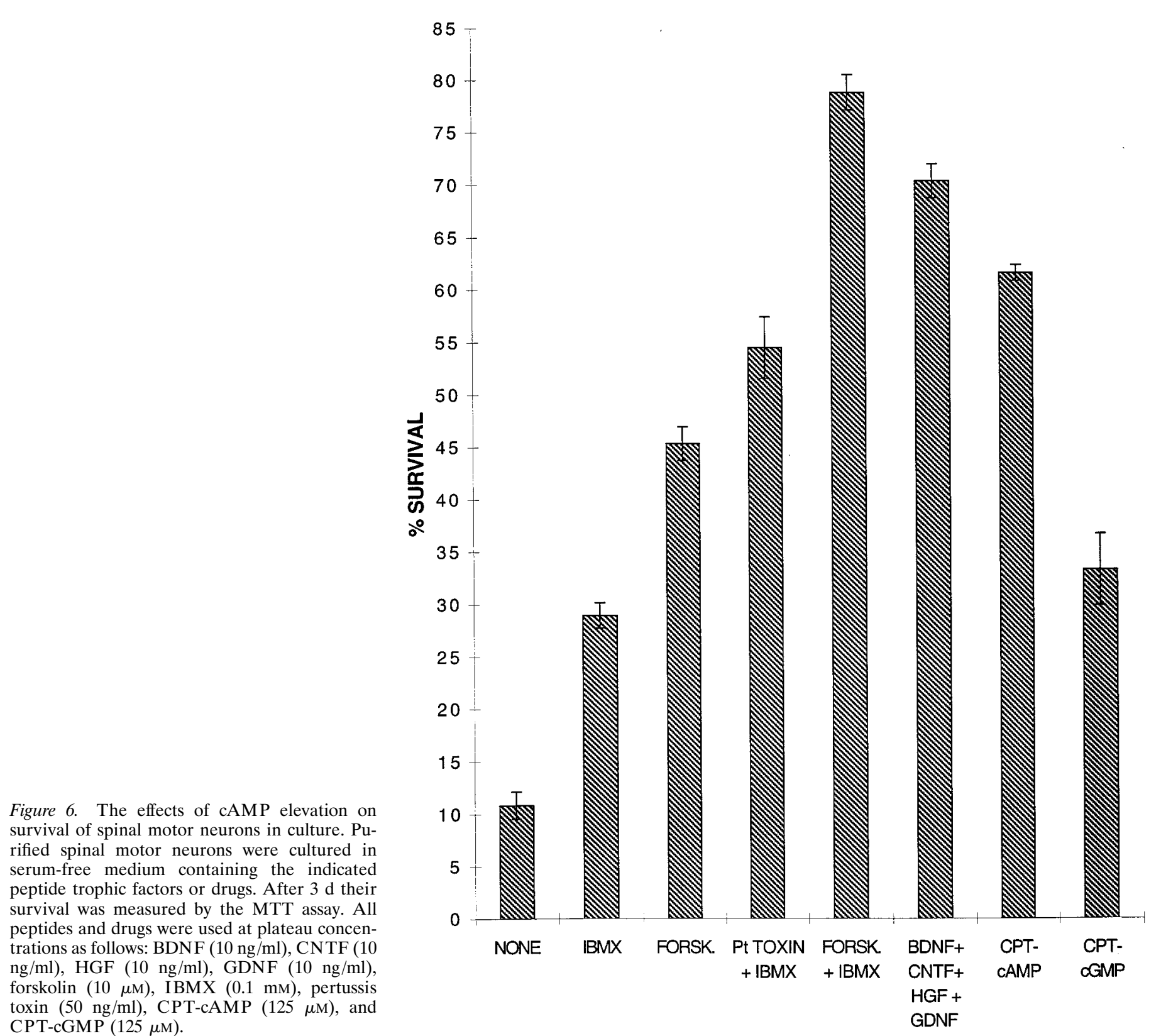

\section{DISCUSSION}

\section{Single peptide trophic factors are not sufficient to promote the short- or long-term survival of the majority of SMNs in vitro}

It has been reported repeatedly that single peptide trophic factors are sufficient to promote the short-term survival of the majority of SMNs (Henderson et al., 1993, 1994; Pennica et al., 1996). Our findings are not in agreement with these latter reports. Although we were able to confirm that a large variety of single peptides is sufficient to promote the survival of some SMNs, in no case did we find single peptides that were sufficient to promote short- or long-term survival of the majority of SMNs. At most, we observed that a single peptide could promote the survival of approximately one-third of the cells for $\sim 3 \mathrm{~d}$. Using similar immunopanning methods and culture medium, however, we have found repeatedly that we can promote the survival of the majority of cells in cultures of defined types of PNS neurons with single peptides (Meyer-Franke et al., 1998). We believe that there are two explanations for the previously reported ability of single peptides to promote the survival of most SMNs in culture. First, horse serum, which contains a large variety of known and unknown peptide trophic factors and also doubles intracellular levels of cAMP (our unpublished observations), was added to the culture medium in these previous reports. Second, the survival of the cells in these studies was normalized for initial viability by dividing all survival values by the initial viability at 15-24 hr. Although this is intended to normalize for necrotic injury to cells during the isolation procedure, it also subtracts death caused by apoptosis. The large majority of SMNs die by apoptosis in $24 \mathrm{hr}$ when appropriate trophic signals are not present. We have avoided these issues by omitting the use of serum in our culture medium and by normalizing all of our survival values to the $1 \mathrm{hr}$ viability (typically $\sim 91 \%$ ).

Our data are also not in agreement with the possibility that single peptide trophic factors might significantly promote the long-term survival of subsets of motor neurons; if this were the 


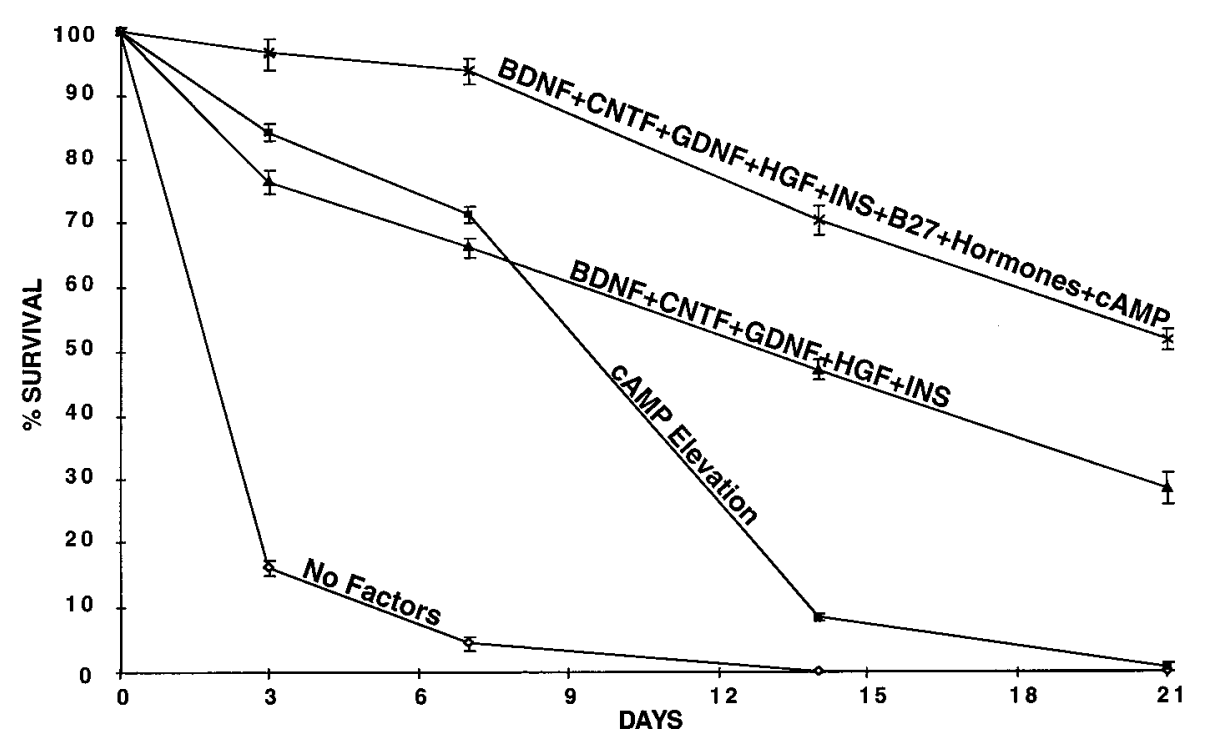

Figure 7. The effects of combining survival factors on long-term survival. The survival of purified spinal motor neurons cultured in the indicated factors was assessed after 3, 7, 14, and $21 \mathrm{~d}$ of culture by the MTT assay. cAMP Elevation was produced by forskolin $(10 \mu \mathrm{M})$ plus IBMX $(0.1$ $\mathrm{mM})$. Hormones are a combination of DHT, estradiol, and hydrocortisone at plateau levels. The medium also contained insulin $(5 \mu \mathrm{g} / \mathrm{ml})$. Results are mean $\pm \operatorname{SEM}(n=3)$ of a representative experiment; all experiments were repeated at least three times. case, then single peptide trophic factors should have been sufficient to promote the long-term survival of a subset of motor neurons. We did not observe this; rather, we observed that single peptides promoted the survival of a small percentage of cells for $3 \mathrm{~d}$, but by $7 \mathrm{~d}$ nearly all of the SMNs had died.

The large variety of different peptides that can promote the survival of SMNs is remarkable. Peptides from nearly all major classes of trophic factors are able to promote the survival of the embryonic SMNs. In addition to the previously reported ability of FGF, GDNF, CNTF, LIF, CT-1, TGF- $\beta$, IGF-1, HGF, and neurotrophins to promote SMN survival, we found that a variety of bone morphogenetic proteins, including BMP-2, BMP-4, and BMP-7, also significantly promotes the short-term survival of a subset of SMNs. Schwann cells have been reported to release trophic activities that promote motor neuron survival, including neurotrophins, cytokines, and GDNF; they also produce BMP-7 (Lein et al., 1996), and thus it is likely that BMP-7 contributes to this Schwann cell-derived trophic activity for SMNs. Interestingly, whereas BMPs such as BMP-7 have been reported to promote the differentiation of neural cells (Liem et al., 1995; Lein et al., 1996; Mabie et al., 1997), to our knowledge this is the first example of a survival-promoting effect by the BMPs.

\section{Multiple trophic factors collaborate to promote survival of each SMN}

Our experiments confirm the remarkable ability of peptide trophic factors to collaborate in promoting the survival of embryonic SMNs (Arakawa et al., 1990; Mitsumoto et al., 1994; Wong et al., 1997; Yamamoto et al., 1997). It has not been clear, however, to what extent a combination of the known peptides is sufficient to promote long-term survival of most of the SMNs. Our results indicate that a combination of up to seven different peptide trophic factors is sufficient only to promote the survival of approximately one-half of the SMNs in serum-free medium. Although it is likely that there are important trophic activities for SMNs that await identification, our data indicate that the activation of second messenger pathways not normally activated by peptide trophic factors also may collaborate in promoting survival. Thus long-term survival of most SMNs is attained when they are cultured in a combination of peptides normally expressed by Schwann cells and muscle cells, together with cAMP elevation.

\section{cAMP elevation is sufficient to promote the survival of the majority of SMNs}

The most important finding in this study is that the elevation of intracellular levels of cAMP is sufficient to promote the survival and growth of SMNs cultured in serum-free medium in the absence of peptide trophic factors. Although cAMP elevation has been found previously to promote survival and growth factor independence in a variety of PNS neurons, SMNs are the first class of CNS neurons for which this is the case. cAMP elevation has been reported to enhance the responsiveness of retinal ganglion cells to their peptide trophic factors (Meyer-Franke et al., 1995, 1998), but in contrast to these cells the SMNs clearly responded well to single peptides without the need to elevate cAMP levels or other second messengers. It is unlikely, however, that cAMP promotes survival of the SMNs by potentiating the effects of autocrine peptides released into the culture medium, because cAMP-stimulated survival was not strongly dependent on cell density. In contrast, survival of the SMNs cultured in single peptide trophic factors was strongly dependent on density; this is not surprising in view of the collaborative effects of peptides on SMN survival and the fact that SMNs express a variety of trophic peptides such as NT-3.

How does the elevation of cAMP promote survival of the SMNs? The ability of cAMP elevation to promote the survival of PNS neurons has been well described for $>30$ years, but the mechanism is unknown. In the SMNs, cAMP elevation mimicked several different actions of peptide growth factors, because it promoted cell survival as well as survival and growth of their processes, suggesting that growth factors normally might promote SMN survival by elevating cAMP. This is not the case, however, because combinations of trophic peptides did not elevate cAMP levels in the SMN cultures. CAMP elevation might promote survival by blocking the apoptosis pathway, for instance by elevating bcl-2 levels or decreasing bax levels, both of which previously have been shown to be sufficient to promote SMN survival (Dubois-Dauphin et al., 1994; Farlie et al., 1995; Sagot et al., 1995). However, sympathetic ganglion neurons that lack bax survive in culture in the absence of peptide trophic factors but do not extend processes (Deckwerth et al., 1996). An interesting alternative possibility is that cAMP elevation in SMNs activates 
a signal transduction pathway normally activated by multiple growth factors. Consistent with this possibility, protein kinase A activation recently has been shown to activate the serine-threonine kinase B-raf, which in turn activates MAP kinase that promotes the survival of PC12 cells in culture, thus mimicking the effects of NGF (Vossler et al., 1997). Consistent with this possibility, we were able to block the cAMP-promoted survival of the SMNs with several protein kinase A inhibitors. Moreover, transgenic animals deficient in B-raf have reduced neuronal survival dramatically (Pritchard and McMahon, 1997; Wojnowski et al., 1997). Because SMNs in culture express B-raf (P. Stork, M. Hanson, and B. Barres, unpublished observations), this possibility merits future investigation.

Our data do not rule out the possibility that cAMP also helps to promote the survival of motor neurons by enhancing their responsiveness to trophic factors, in addition to its ability to make them growth factor-independent. Several lines of evidence suggest that cAMP may, in fact, enhance trophic responsiveness. First, the survival of the SMNs cultured in single peptide trophic factors was increased substantially by cAMP elevation, and protein kinase A inhibitors blocked the ability of peptides to promote SMN survival. Moreover, we recently have found that cAMP elevation significantly increases TrkB immunoreactivity on the surfaces of the SMNs in culture (Meyer-Franke et al., 1998). Thus optimal trophic responsiveness of the SMNs very well may depend on basal cAMP levels. These levels might be disrupted in disease processes, and dying SMNS, for instance in amyotrophic lateral sclerosis, may have impaired responsiveness to peptide trophic factors. If so, this would help to account for the so far limited success of the delivery of exogenous peptide trophic factors such as BDNF, CNTF, and IGF-1 in treating ALS patients.

Does cAMP normally help to promote SMN survival in vivo? Although cAMP elevation was sufficient to promote survival of most of the SMNs for at least 1 week in culture, survival decayed with longer culture periods, as it did with combinations of peptides in the absence of cAMP elevation. Remarkably, however, we found that we could promote the long-term survival of most of the cells for 3 weeks when we used cAMP elevation together with a combination of peptide trophic factors. These findings suggest the possibility that the regulation of cAMP levels normally may play an important role in the control of SMN survival in vivo. In any case, these simple defined culture conditions now provide a preparation in which the behavior of motor neurons and their interactions with other cell types may be studied in long-term culture.

\section{Implications for survival and regeneration of SMNs after injury and in neurodegenerative disease}

In addition to possible therapeutic applications of our findings, our data are also potentially relevant to understanding why CNS and PNS neurons have radically different abilities to survive and regenerate their axons in response to axotomy. Whereas PNS neurons survive and regenerate, many types of CNS neurons die and do not regenerate, particularly long projection glutamatergic neurons. It recently has been hypothesized that this lesser ability of CNS neurons to survive and regenerate is attributable at least in part to the more complex signaling mechanisms that regulate their survival and growth (Snider, 1994; Meyer-Franke et al., 1995). Remarkably, SMNs, although they are CNS neurons, share the ability with PNS neurons to both survive and regenerate after injury and to survive and grow in response to cAMP elevation.
When the axons of CNS and PNS neurons are severed, they are cut off from important glial-derived and target-derived trophic peptide signals. The presence of another mechanism that is sufficient to promote survival and growth in the absence of trophic peptide signaling obviously could be crucial for SMNs and PNS neurons to survive and regenerate after injury. It is possible that target-derived signals normally might act to depress cAMP signals and that this inhibition is released after axotomy. Consistent with this possibility, calcitonin gene-related peptide, which increases cAMP levels, is upregulated in SMNs after axotomy (Zigmond and Sun, 1997), but it is not known whether cAMP levels increase in axotomized SMNs and PNS neurons. Last, our findings raise the question of whether the survival of other types of CNS cholinergic neurons, such as cholinergic neurons in the basal forebrain, which share the ability of SMNs to survive and regenerate after axotomy, is promoted by cAMP elevation.

\section{REFERENCES}

Arakawa Y, Sendtner M, Thoenen H (1990) Survival effect of ciliary neurotrophic factor (CNTF) on chick embryonic motoneurons in culture: comparison with other neurotrophic factors and cytokines. J Neurosci 10:3507-3515.

Arce V, Pollock R, Philippe J, Pennica D, Henderson C, deLapeyriere O (1998) Synergistic effects of Schwann- and muscle-derived factors on motoneuron survival involve GDNF and cardiotrophin-1. J Neurosci 18:1440-1448.

Barbin G, Manthorpe M, Varon S (1984) Purification of the chick eye ciliary neurotrophic factor. J Neurochem 43:1468-1478.

Barde YA (1989) Trophic factors and neuronal survival. Neuron 2:1525-1534.

Barde YA (1990) The nerve growth family. Prog Growth Factor Res 2:237-248.

Bitgood MJ, McMahon AP (1995) Hedgehog and BMP genes are coexpressed at many diverse sites of cell-cell interaction in the mouse embryo. Dev Biol 172:126-138.

Botelho LH, Rothermal JD, Coombs RV, Jastorff B (1988) cAMP analog antagonists of cAMP action. Methods Enzymol 159:159-172.

Bottenstein JE, Sato GH (1979) Growth of a rat neuroblastoma cell line in serum-free supplemented medium. Proc Natl Acad Sci USA 76:514-517.

Brewer J, Torricelli JR, Evege EK, Price PJ (1993) Optimized survival of hippocampal neurons in B27-supplemented neurobasal, a new serum-free medium combination. J Neurosci Res 35:567-576.

Buckmaster EA, Tolkovsky AM (1994) Expression of the cAMPdependent protein kinase A catalytic subunit from a herpes simplex virus vector extends the survival of rat sympathetic neurons in the absence of NGF. Eur J Neurosci 6:1316-1327.

Camu W, Henderson CE (1992) Purification of embryonic rat motoneuron by panning on a monoclonal antibody to the low-affinity NGF receptor. J Neurosci Methods 44:59-70.

Camu W, Henderson CE (1994) Rapid purification of embryonic rat motoneurons: an in vitro model for studying MND/ALS pathogenesis. J Neurol Sci 124[Suppl]:73-74.

Chijiwa T, Mishima A, Hagiwara M, Sano M, Hayashi K, Inouse T, Naito K, Toshioka T, Hidaka H (1990) Inhibition of forskolin-induced neurite outgrowth and protein phosphorylation by a newly synthesized selective inhibitor or cAMP-dependent protein kinase, H89, of PC12D pheochromocytoma cells. J Biol Chem 265:5267-5272.

Deckwerth TL, Elliott JL, Knudson CM, Johnson Jr EM, Snider WD, Korsmeyer SJ (1996) BAX is required for neuronal death after trophic factor deprivation and during development. Neuron 17:401-411.

Dubois-Dauphin M, Frankowski H, Tsujimoto Y, Huarte J, Martinou JC (1994) Neonatal motoneurons overexpressing the $b c l$-2 protooncogene in transgenic mice are protected from axotomy-induced cell death. Proc Natl Acad Sci USA 91:3309-3313.

Ebens A, Brose K, Leonardo DE, Hanson MG, Friedhelm B, Birchmeier C, Barres BA, Tessier-Lavigne M (1996) Hepatocyte growth factor/ scatter factor is an axonal chemoattractant and a neurotrophic factor for spinal motor neurons. Neuron 17:1157-1172.

Ericson J, Thor S, Edlund T, Jessell TM, Yamada T (1992) Early stages of motor neuron differentiation revealed by expression of homeobox gene islet-1. Science 256:1555-1560. 
Farlie PG, Dringen R, Rees SM, Kannourakis G, Bernard O (1995) bcl-2 transgene expression can protect neurons against developmental and axotomy-induced cell death. Proc Natl Acad Sci USA 92:4397-4401.

Franklin JL, Johnson Jr EM (1992) Suppression of programmed neuronal death by sustained elevation of cytoplasmic calcium. Trends Neurosci 15:501-508.

Henderson CE, Camu W, Mettling C, Gouin A, Berkemeier L, Phillips HS, Rosenthal A (1993) Neurotrophins promote motor neuron survival and are present in embryonic limb bud. Nature 363:266-270.

Henderson CE, Phillips HS, Pollock RA, Davies AM, Lemeulle C, Armanini M, Simpson LC, Moffet B, Vandlen RA, Koliatsos VE, Rosenthal A (1994) GDNF: a potent survival factor for motor neurons present in peripheral nerve and muscle. Science 266:1062-1064.

Hogan B (1996) Bone morphogenetic proteins: multifunctional regulators of vertebrate development. Genes Dev 10:1580-1594.

Hughes RA, Sendtner M, Thoenen H (1993) Members of several gene families influence survival of rat motor neurons in vitro and in vivo. J Neurosci Res 36:663-671.

Jung W, Castren E, Odenthal M, Vande Woude GF, Ishii T, Dienes H-P, Lindholm D, Schirmacher P (1994) Expression and functional interaction of hepatocyte growth factor-scatter factor and its receptor c-met in mammalian brain. J Cell Biol 126:485-494.

Koike T, Tanaka S (1991) Evidence that nerve growth factor dependence of sympathetic neurons for survival in vitro may be determined by levels of cytoplasmic free calcium. Proc Natl Acad Sci USA 88:3892-3896.

Koliatsos VE, Clatterbuck RE, Winslow JW, Cayouette MH, Price DL (1993) Evidence that brain-derived neurotrophic factor is a trophic factor for motor neurons in vivo. Neuron 10:359-367.

Lein P, Guo X, Hedges AM, Rueger D, Johnson M, Higgins D (1996) The effects of extracellular matrix and osteogenic protein 1 on the morphological differentiation of rat sympathetic neurons. Int $\mathrm{J}$ Dev Neurosci 14:203-215.

Levi-Montalcini R (1987) The nerve growth factor: 35 years later. EMBO J 6:1145-1154.

Li L, Wu W, Lin LF, Lei M, Oppenheim RW, Houenou LJ (1995) Rescue of adult mouse motoneurons from injury-induced cell death by glial cell line-derived neurotrophic factor. Proc Natl Acad Sci USA 92:9771-9775.

Li M, Sendtner M, Smith A (1995) Essential function of LIF receptor in motor neurons. Nature 378:724-727.

Liem KF, Tremml G, Roelink H, Jessell TM (1995) Dorsal differentiation of neural plate cells induced by BMP-mediated signals from epidermal ectoderm. Cell 82:969-979.

Lillien LE, Raff M (1990) Differentiation signals in the CNS: type-2 astrocyte development as a model system. Neuron 5:110-119.

Mabie PC, Mehler MF, Marmur R, Papavasiliou A, Song Q, Kessler JA (1997) Bone morphogenetic proteins induce astroglial differentiation of oligodendroglial-astroglial progenitor cells. J Neurosci 17:4112-4120.

Martinou JC, Martinou I, Kato AC (1992) Cholinergic differentiation factor $(\mathrm{CDF} / \mathrm{LIF})$ promotes survival of isolated rat embryonic motoneurons in vitro. Neuron 8:737-744.

Masu Y, Wolf E, Holtmann B, Sendtner M, Brem G, Thoenen H (1993) Disruption of the CNTF gene results in motor neuron degeneration. Nature 365:27-32.

McAllister AK, Katz LC, Lo DC (1996) Neurotrophin regulation of cortical dendritic growth requires activity. Neuron 17:1057-1064.

McKay SE, Garner A, Caldero J, Tucker RP, Large T, Oppenheim RW (1996) The expression of trkB and p75 and the role of BDNF in the developing neuromuscular system of the chick embryo. Development 122:715-724.

Meyer-Franke A, Kaplan MR, Pfrieger FW, Barres BA (1995) Characterization of the signaling interactions that promote the survival and growth of developing retinal ganglion in culture. Neuron 15:805-819.

Meyer-Franke A, Wilkinson G, Reichardt L, Barres BA (1998) Cyclic AMP elevation and depolarization enhance BDNF responsiveness of retinal ganglion cells by recruiting trkB to the plasma membrane. Neuron, in press.

Mitsumoto H, Ikeda K, Klinkosz B, Cedarbaum JM, Wong V, Lindsay RM (1994) Arrest of motor neuron disease in wobbler mice cotreated with BDNF and CNTF. Science 265:1107-1110.
Mosmann T (1983) Rapid colorimetric assay for cellular growth and survival: application to proliferation and cytotoxicity assays. J Immunol Methods 65:55-63.

Neff NT, Prevette D, Houenou LJ, Lewis ME, Glicksman MA, Yin QW, Oppenheim RW (1993) Insulin-like growth factors: putative musclederived trophic agents that promote motor neuron survival. J Neurobiol 24:1578-1588.

Oppenheim RW (1996) Neurotrophic survival molecules for motoneurons: an embarrassment of riches. Neuron 17:195-197.

Oppenheim RW, Houenou LJ, Johnson JE, Lin LF, Li L, Lo AC, Newsome AL, Prevette DM, Wang S (1995) Developing motor neurons rescued from programmed and axotomy-induced cell death by GDNF. Nature 373:344-346.

Pennica D, Arce V, Swanson TA, Vejsada R, Pollock RA, Armanini M, Dudley K, Phillips HS, Rosenthal A, Kato AC, Henderson CE (1996) Cardiotrophin-1, a cytokine present in embryonic muscle, supports long-term survival of spinal motoneurons. Neuron 17:63-74.

Pritchard C, McMahon M (1997) Raf revealed in life or death decisions. Nat Genet 16:214-215.

Rydell RE, Greene LA (1988) cAMP analogs promote survival and neurite outgrowth in cultures of rat sympathetic and sensory neurons independently of NGF. Proc Natl Acad Sci USA 85:1257-1261.

Sagot Y, Dubois-Dauphin M, Tan SA, de Bilbao F, Aebischer P, Martinou JC, Kato AC (1995) bcl-2 overexpression prevents motoneuron cell body loss but not axonal degeneration in a mouse model of a neurodegenerative disease. J Neurosci 15:7727-7733.

Sendtner M, Holtmann B, Kolbeck R, Thoenen H, Barde YA (1992a) Brain-derived neurotrophic factor prevents the death of motoneurons in newborn rats after nerve section. Nature 360:757-759.

Sendtner M, Schmalbruch H, Stockli KA, Carroll P, Kreutzberg GW, Thoenen H (1992b) Ciliary neurotrophic factor prevents degeneration of motor neurons in mouse mutant progressive motor neuropathy. Nature 358:502-504.

Sendtner M, Gotz R, Holtmann B, Escary JL, Masu Y, Carroll P, Wolf E, Brem G, Brulet P, Thoenen H (1996) Cryptic physiological trophic support of motoneurons by LIF revealed by double gene targeting of CNTF and LIF. Curr Biol 6:686-694.

Snider WD (1994) Functions of the neurotrophins during nervous system development: what the knockouts are teaching us. Cell 77:627-638.

Tsuchida T, Ensini M, Morton SB, Baldassare M, Edlund T, Jessell TM, Pfaf SL (1994) Topographic organization of embryonic motor neurons defined by expression of LIM homeobox genes. Cell 79:957-970.

Vossler MR, Yao H, York RD, Pan MG, Rim CS, Stork PJ (1997) cAMP activates MAP kinase and Elk-1 through a B-raf- and Rap1dependent pathway. Cell 89:73-82.

Wakada AR, Edgar D, Thoenen H (1983) Both nerve growth factor and high $\mathrm{K}^{+}$concentrations support the survival of chick embryo sympathetic neurons. Exp Cell Res 144:377-384.

Weill CL, Green DP (1984) Prevention of natural motor neurone cell death by dibutyryl cyclic GMP. Nature 308:452-454.

Wiemelt A, Engleka MJ, Skorupa A, McMorris FA (1997) Immunochemical visualization and quantitation of cyclic AMP in single cells. J Biol Chem 272:31489-31495.

Wojnowski L, Zimmer AM, Beck TW, Hahn H, Bernal R, Rapp UR, Zimmer A (1997) Endothelial apoptosis in B-raf deficient mice. Nat Genet 16:293-297.

Wong V, Glass DJ, Arriaga R, Yancopoulos GD, Lindsay RM, Conn G (1997) Hepatocyte growth factor promotes motor neuron survival and synergizes with ciliary neurotrophic factor. J Biol Chem 272:5187-5191.

Yamamoto Y, Livet J, Pollock RA, Garces A, Arce V, deLapeyriere O, Henderson CE (1997) Hepatocyte growth factor (HGF/SF) is a muscle-derived survival factor for a subpopulation of embryonic motor neurons. Development 124:2903-2913.

Yan Q, Elliott J, Snider WD (1992) Brain-derived neurotrophic factor rescues spinal motor neurons from axotomy-induced cell death. Nature 360:753-759.

Zigmond RE, Sun Y (1997) Regulation of neuropeptide expression. Paracrine and retrograde influences. Ann NY Acad Sci 814:181-197.

Zurn AD, Werren F (1994) Development of CNS cholinergic neurons in vitro: selective effects of CNTF and LIF on neurons from mesencephalic cranial motor nuclei. Dev Biol 163:309-315. 